bound to the membrane (in that it resists washing out by the normal flow of secretions). A firmly bound effect was therefore sought by exposing normal red cells to saliva for $5 \mathrm{~min}$, and then washing, before measuring ouabain-insensitive efflux. Table 2 shows that there was no difference between cells exposed to saliva and then washed, and cells not exposed to saliva. No firmly bound factor was demonstrated.

The significance of humoral substances affecting membrane transport remains to be clarified. There does not appear to be any known hormone, for example, which could easily explain the above effect of saliva, whereas simple physical or physicochemical factors would seem to be excluded by the experimental controls. Modification of the cell membrane by uncharacterized circulating or secreted factors may have a bearing on transport processes in general, and possibly on the disturbance of CF in particular. However, the red cell model, as used in this study, has not confirmed that such a mechanism is important in CF.

\section{CONCLUSION}

In a preliminary study, the red blood cells of patients with cystic fibrosis were found to show decreased ouabain-insensitive $\mathrm{Na}^{+}$efflux. The ouabain-sensitive $\mathrm{Na}^{+}$efflux, total $\mathrm{Na}^{+}$efflux, and $\mathrm{Na}^{+}$influx were found to be normal. This information was used to guide the choice of transport parameters in the main study. The effect of cystic fibrosis saliva on normal red cells was not significantly different from that of control saliva, but both

Copyright (C) 1978 International Pediatric Research Foundation, Inc 0031-3998/78/0012-0001\$02.00/0

normal saliva and cystic fibrosis saliva appear to contain a substance which accelerates $\mathrm{Na}^{+}$transport in the red cell

\section{REFERENCES AND NOTES}

1. Balfe, J. W., Cole, C., and Welt, L. G.: Red cell transport defect in patients with cystic fibrosis and in their parents. Science, 162: 689 (1968)

2. Di Sant'Agnese, P. A., and Talamo, R. C.: Pathogenesis and pathophysiology of cystic fibrosis of the pancreas. New Engl. J. Med., 277: 1344 (1967).

3. Duffy, M. J., and Schwarz, V.: Cystic fibrosis and membrane transport Lancet, ii: 136 (1972)

4. Hoffman, J. F., and Kregenow, F. M.: The characterization of new energy dependent cation transport processes in red blood cells. Ann. N. Y. Acad Sci., 137: 566 (1966)

5. Kaiser, D., Drack, E., and Rossi, E.: Effect of cystic fibrosis sweat on sodium transport by the normal sweat gland. Lancet, $i: 1003(1970)$

6. Lapey, A., and Gardner, J. D.: Abnormal erythrocyte sodium transport in cystic fibrosis of the pancreas. Pediat. Res., 5: 446 (1971).

7. Mangos, J. A., McSherry, N. R., and Benke, P. J.: A sodium transport inhibitory factor in the saliva of patients with cystic fibrosis of the pancreas. Pediat. Res., 1: 436 (1967).

8. Sachs, J. R., and Welt, L. G.: The concentration dependence of active potassium transport in the human red blood cell. J. Clin. Invest., 46: 65 (1967).

9. Taussig, L. M., and Gardner, J. D.: Effects of saliva and plasma from cystic fibrosis patients on membrane transport. Lancet, $i$ : 1367 (1972).

10. The authors thank Dr. J. C. Batten, Brompter Hospital, London, for his interest in this work and for permission to study some of his patients.

11. Financial support was provided by the Cystic Fibrosis Research Trust.

12. Requests for reprints should be addressed to: P. M. Grinwald, M.D. Sherrington School of Physiology, St. Thomas's Hospital Medical School, Lambeth Palace Road, London, SE1 7EH (England)

13. Received for publication October 22,1976

14. Accepted for publication April 12, 1977.

Pediat. Res. 12: 3-6 (1978)

Kidney

low birth weight infants myoinositol

renal function

\title{
Myoinositol in Human Neonates: Serum Concentrations and Renal Handling
}

\author{
L. M. LEWIN, S. MELMED ${ }^{(18)}$ J. H. PASSWELL, Y. YANNAI, M. BRISH, S. ORDA, H. BOICHIS \\ AND $H$. BANK \\ Department of Chemical Pathology, Sackler School of Medicine, Tel-Aviv University, and Departments of \\ Medicine and Pediatrics, Chaim Sheba Medical Centre, Tel Hashomer, Israel
}

\section{Summary}

Free myoinositol (henceforth called inositol) levels were measured in cord blood from newborns, as well as in sera from lealthy infants during the first 6 months of life. Renal excretion f inositol by a group of premature infants during their first 2 nonths of life was also studied. Inositol was measured by nicrobiologic assay, using an inositol-requiring yeast, Sacchaomyces carlsbergensis. Inositol concentration in pooled cord iamples of full term normal newborns was $25 \pm 5.3 \mu \mathrm{g} / \mathrm{ml}$. These levels dropped progressively, reaching adult levels (6.9 $\mathrm{\imath g} / \mathrm{ml}$ ) by the eighth week of life. Mean concentration of nositol in cord blood of premature neonates was $30 \mu \mathrm{g} / \mathrm{ml}$.

In premature infants, the inositol content in the urine was lways higher than that of the blood; the average urine concenration was $198 \mu \mathrm{g} / \mathrm{ml}$. Inositol clearance values of premature nfants ranged from $0.10-0.79 \mathrm{ml} / \mathrm{min}$ and averaged $0.34 \mathrm{ml} /$ nin, and were thus lower than the mean inositol clearances of nonuremic normal adults $(2.8 \mathrm{ml} / \mathrm{min})$. The total amounts of inositol excreted per day by the premature infants were considerably higher than the amounts ingested. The blood inositol concentrations in infants in this study are similar to those found in adults with impaired renal function.

The inositol status of the neonate appears to be determined by a balance between the two factors which tend to increase the amount of inositol available, that is, biosynthesis of inositol and ingestion with the formula; and the two factors which decrease the blood level, i.e., kidney maturation with resultant increased inositol clearance and, possibly, renal enzymatic catabolism of inositol.

\section{Speculation}

The rat kidney regulates blood inositol concentration via catabolism by an inositol oxidase. Impaired renal function in man is accompanied by raised serum levels of inositol, as well 
as increased urinary inositol excretion. This is particularly relevant in view of the association of uremic neuropathy with high serum inositol concentration. The current finding of a similar situation in premature infants may lend further support to the assumption that inositol homeostasis in man is achieved by renal enzymatic catabolism, as well as by glomerular excretion.

Myoinositol, which is known to be a growth factor for some microorganisms and for a number of mammalian species, as well as for human cells in tissue culture (5), has been reported to be present at a higher concentration in fetal than in adult blood in a variety of mammalian species $(2,3)$. The high fetal blood concentrations observed in the cat, rabbit, and rat were seen to decrease to normal adult levels by the end of the first three weeks of postnatal life (3). In this study, changes in free myoinositol (henceforth called inositol) levels were measured in pooled serum samples of cord blood from newborns, as well as from serum samples from healthy infants during their first 6 months of life. Since elevated serum inositol concentrations in adults were found to correlate with impaired renal function $(4$, $10,15)$, we also studied the renal handling of inositol by a group of premature infants during their first 2 months of life.

\section{MATERIALS AND METHODS}

In order to determine serum inositol concentrations, blood samples were obtained from cord bloods of 30 premature (less than 37 weeks of gestational age) and 75 full-term healthy newborns, as well as from 35 nonuremic infants admitted for surgical procedures. These samples were pooled according to the age of the infant. Normal control samples were taken from 44 nonuremic adults. Serum was deproteinized and inositol measured as described below.

Urine collections for clearance studies were done as previously described (14). Venous blood for inositol and creatinine assay was withdrawn at the end of the urine collections. Blood and urine creatinine levels were determined by the method of Jaffe. The inositol concentrations of serum and milk were determined after deproteinization with trichloroacetic acid and neutralization with Dowex 1-OH resin; urine inositol levels were measured after deionization with Amberlite MB 3 mixed ion exchange resin, as previously described (9). The microbiologic assay of McKibbin (12), using an inositol-requiring yeast, Saccharomyces carlsbergensis ATCC 9080 , was used.

All of the preterm infants studied had appropriate weights for gestational age and had not had any perinatal disease. Informed consent was obtained for the clearance studies.

Renal clearances of inositol were determined in two groups of infants. Group I was comprised of 10 infants whose birthweight ranged from 1.43-2.08 $\mathrm{kg}$ and who were between 3 and 33 days old on the day of the study. This group was fed $150 \mathrm{ml} /$ $\mathrm{kg}$ /day of a mixture of cow's milk (2 parts) and water (1 part). Group II was comprised of seven infants whose birth- weight ranged from $1.35-1.97 \mathrm{~kg}$ and who were 11-50 days old on the day of the study. These infants were fed $150 \mathrm{ml} / \mathrm{kg} /$ day of Similac (Ross Laboratories). Included in this group is one infant who was fed breast milk and one who was fed both cow's and mother's milk.

\section{RESULTS}

Inositol concentration in pooled cord blood samples of fullterm normal newborns was $25 \pm 5.3 \mu \mathrm{g} / \mathrm{ml}$, compared to the mean adult concentration of $6.9 \mu \mathrm{g} / \mathrm{ml}$ which we determined previously $(9,11)$. These high concentrations of inositol found in full-term newborns dropped abruptly and reached adult levels by the eighth week after birth (Fig. 1). Concentrations found in similar pooled samples from premature neonates ranged from $18-47 \mu \mathrm{g} / \mathrm{ml}$ with a mean of $30 \mu \mathrm{g} / \mathrm{ml}$.
The inositol concentrations in the serum from the infants of both groups shown in Table 1 averaged $39 \mu \mathrm{g} / \mathrm{ml}$. The inositol content in the urine was always higher than that of the blood, and the average urine concentration was $198 \mu \mathrm{g} / \mathrm{ml}$ (Table 1). Inositol clearance values ranged from $0.10-0.79 \mathrm{ml} / \mathrm{min}$ and averaged $0.34 \mathrm{ml} / \mathrm{min}$. This is lower than the mean inositol clearance value of nonuremic, normal adults $(2.8 \mathrm{ml} / \mathrm{min})(11)$. Mean creatinine clearance in the preterm infants studied was $1.60 \mathrm{ml} / \mathrm{min}$.

The maximum amount of inositol ingested was calculated based on the inositol concentration which we measured in Similac $(15 \mu \mathrm{g} / \mathrm{ml})$ and on the mean of inositol concentrations in cow's milk measured by Ogasa et al ., using microbiologic and gas chromatographic methods (approximately $37 \mu \mathrm{g} / \mathrm{ml}$ ) (13). The total amounts of inositol excreted per day were generally considerably higher than the amounts ingested in the formula.

\section{DISCUSSION}

The concentrations of inositol which we have found in the serum of newborn infants and in neonates were approximately 3-6 times the normal adult level. This is consistent with reports of elevated inositol levels in fetal serum from a variety of mammalian species. Fetal blood contained higher levels of inositol than maternal blood, which had a normal adult concentration (3). The early high inositol concentrations drop to approximately normal adult levels within a few months after birth.

The kidney is probably the major organ regulating blood inositol concentration (8). High serum inositol concentrations are found in patients with impaired renal function $(4,10)$. The kidney may control blood levels of inositol partly by excretion and partly by catabolism of inositol to D-glucuronic acid, which may be further catabolized to $\mathrm{CO}_{2}(7)$. The blood inositol concentrations in infants in our study were similar to those found in adults with impaired renal function (11). Furthermore, inositol concentration in the urine of these infants was extremely high, whereas the inositol clearance values (mean $0.34 \mathrm{ml} / \mathrm{min}$ ) were much lower than those of normal adults (mean $2.8 \mathrm{ml}$ / $\mathrm{min})$. This is probably a consequence, at least in part, of the lower glomerular filtration rate in preterm infants $(6,14)$. However, despite the limited ability of the kidneys of the infants to excrete inositol, the renal excretion generally exceeded the intake of inositol from either the cow's milk formula group (group I) or from the Similac or mother's milk group (group II). This may indicate that the excess inositol was derived from biosynthesis, or that these infants have a large endogenous store, from which they excreted inositol.

Campling and Nixon (3) showed that the high fetal blood inositol concentration in sheep was not due to maternal transfer via the placenta or to placental synthesis. They concluded that the excess inositol must therefore be synthesized by the fetus. Andrews (1) showed that perfused fetal sheep livers were capable of synthesizing inositol. Subsequently, in studies in the rat, Burton and Wells (2) demonstrated that the fetal liver accounted for over $48 \%$ of the total inositol synthesizing cyclase enzyme. This increasing enzyme activity in the liver declined to adult levels by the 12 th postpartum day. In the rat, therefore, the liver appears to be the source of the increased inositol concentration in the blood of the fetus and newborn. The results observed with inositol excretion in the low birthweight infants in our study suggest that similar inositol-synthesizing ability may exist in the liver of human infants.

Thus, the inositol status of the neonate appears to be determined by a balance between the two factors which tend to increase the amount of inositol available, that is, biosynthesis of inositol and ingestion with the formula; and the two factors which decrease the blood level, i.e., kidney maturation with resultant increased inositol clearance and possible renal catabolism of inositol. 


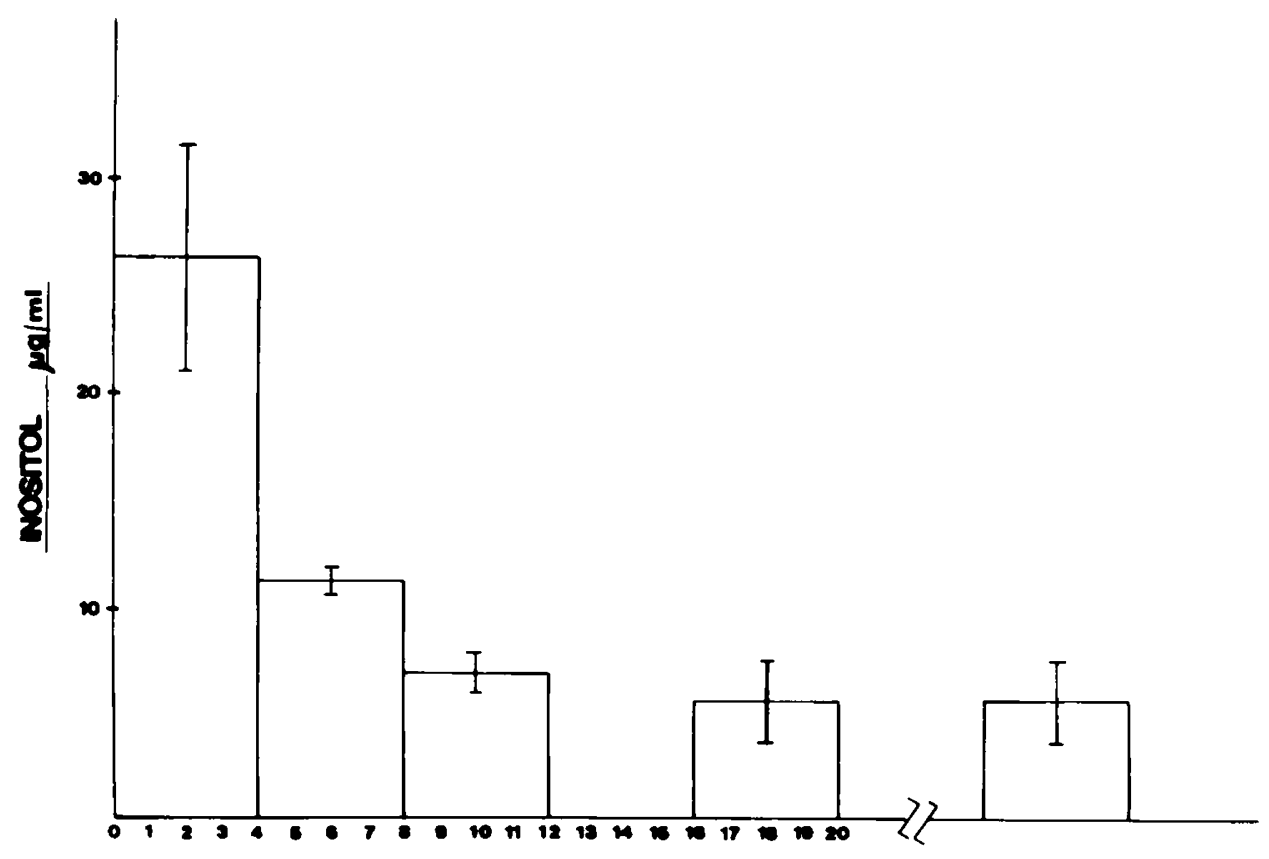

Aes in mense

Adret comprots

Fig. 1. Free myoinositol concentration in the serum of human infants. Results are expressed as means \pm SD.

Table 1. Renal handling of inositol by low birthweight neonates

\begin{tabular}{|c|c|c|c|c|c|c|c|c|c|c|}
\hline \multirow[b]{2}{*}{ Subject } & \multirow[b]{2}{*}{$\begin{array}{l}\text { Age } \\
\text { days }\end{array}$} & \multirow[b]{2}{*}{ Sex } & \multicolumn{2}{|c|}{$\mathrm{Wt}, \mathrm{kg}$} & \multirow{2}{*}{$\begin{array}{l}\text { Creatinine } \\
\text { clearance } \\
(\mathrm{ml} / \mathrm{min}) \\
\text { uncorrected }\end{array}$} & \multicolumn{5}{|c|}{ Inositol } \\
\hline & & & Birth & $\begin{array}{l}\text { Test } \\
\text { date }\end{array}$ & & $\begin{array}{l}\text { Serum, } \\
\mu \mathrm{g} / \mathrm{ml}\end{array}$ & $\begin{array}{l}\text { Urine, } \\
\mu \mathrm{g} / \mathrm{ml}\end{array}$ & $\begin{array}{c}\text { Clearance, } \\
\mathrm{ml} / \mathrm{min}\end{array}$ & $\begin{array}{c}\text { Excreted, } \\
\text { mg/day }\end{array}$ & $\begin{array}{c}\text { Ingested, } \\
\mathrm{mg} / \text { day }\end{array}$ \\
\hline \multicolumn{11}{|l|}{ Group I ${ }^{1}$} \\
\hline 1 & 3 & $\mathrm{~F}$ & 1.84 & 1.91 & 1.02 & 26 & 221 & 0.28 & 10.6 & 7.0 \\
\hline 2 & 8 & $\mathbf{M}$ & 1.76 & 1.74 & 2.19 & 22 & 121 & 0.51 & 16.2 & 6.5 \\
\hline 3 & 10 & $F$ & 1.73 & 1.64 & 1.50 & 34 & 450 & 0.66 & 32.4 & 6.1 \\
\hline 4 & 11 & $\mathrm{~F}$ & 1.66 & 1.60 & 0.78 & 25 & 325 & 0.79 & 28.4 & 5.9 \\
\hline 5 & 20 & F & 1.44 & 1.64 & 1.43 & 33 & 277 & 0.46 & 21.8 & 6.1 \\
\hline 6 & 21 & $F$ & 1.43 & 1.40 & 1.57 & 36 & 93 & 0.19 & 9.9 & 5.2 \\
\hline 7 & 24 & $\mathbf{M}$ & 1.55 & 1.78 & 3.50 & 47 & 71 & 0.23 & 15.3 & 6.6 \\
\hline 8 & 27 & $\mathbf{M}$ & 2.08 & 2.18 & 2.72 & 35 & 147 & 0.64 & 32.1 & 8.1 \\
\hline 9 & 30 & $\mathbf{M}$ & 2.04 & 2.20 & 0.91 & 17 & 132 & 0.24 & 5.8 & 8.2 \\
\hline 10 & 33 & $\mathbf{M}$ & 2.03 & 1.96 & 0.89 & 22 & 43 & 0.16 & 4.9 & 7.3 \\
\hline \multicolumn{11}{|l|}{ Group II ${ }^{2}$} \\
\hline $11^{3}$ & 11 & $\mathbf{M}$ & 1.35 & 1.81 & 0.86 & 28 & 73 & 0.22 & 9.1 & \\
\hline 12 & 11 & $\mathbf{F}$ & 1.67 & 1.74 & 2.73 & 38 & 42 & 0.10 & 5.2 & 5.4 \\
\hline 13 & 11 & $\mathbf{M}$ & 1.95 & 1.94 & 0.48 & 44 & 177 & 0.33 & 20.9 & 5.4 \\
\hline 14 & 13 & $F$ & 1.66 & 1.50 & 0.65 & 39 & 187 & 0.20 & 11.2 & 4.2 \\
\hline 15 & 19 & $F$ & 1.60 & 1.70 & 1.49 & 47 & 87 & 0.13 & 9.0 & 4.8 \\
\hline 16 & 40 & $\mathbf{M}$ & 1.97 & 2.56 & 3.58 & 117 & 73 & 0.14 & 24.1 & 8.4 \\
\hline $17^{4}$ & 50 & $\mathbf{M}$ & 1.90 & 1.38 & 0.87 & 47 & 800 & 0.53 & 36.0 & 31.0 \\
\hline
\end{tabular}

${ }^{1}$ Group I received $150 \mathrm{ml} / \mathrm{kg} /$ day of 2 parts cow's milk and 1 part water.

${ }^{2}$ Group II received $150 \mathrm{ml} / \mathrm{kg} /$ day of Similac formula, except as noted.

${ }^{3}$ Infant received mother's milk and Similac.

${ }^{4}$ Infant received mother's milk.

Since human mother's milk supplies much more inositol than does a cow's milk formula (13), it is possible that the latter formula supplies inositol in less than optimal amounts at a time of life when liver biosynthesis has ceased to play a significant role. The decrease to normal adult concentrations is probably dependent on renal catabolism of the inositol and possibly on the progressive increase in glomerular filtration rate. The biologic role of these increased inositol levels in the first weeks of life needs to be clarified.

\section{REFERENCES AND NOTES}

1. Andrews, W. H. H., Ritton, H. G., Huggett, A. St. G., and Nixon, D. A. Fructose metabolism in the isolated perfused liver of the foetal and newborn sheep. J. Physiol., 153: 199 (1960).

2. Burton, L. E., and Wells, W. W.: Studies on the developmental pattern of the enzymes converting glucose 6-phosphate to myo-inositol in the rat. Devel. Biol., 37: 35 (1974).

3. Campling, J. D., and Nixon, D. A.: The inositol content of foetal blood and foetal fluids. J. Physiol., 126: 71 (1954).

4. Clements, R. S., Jr., DeJesus, P. V., Jr., and Winegrad, A. J.: Raised 
plasma myo-inositol levels in uremia and experimental neuropathy. Lancet, i: 1137 (1973).

5. Eagle, H., Oyama, V. I., Levy, M., and Freeman, A. E.: Myo-inositol as an essential growth factor for normal and malignant human cells in tissue culture. J. Biol. Chem., 226: 191 (1957)

6. Edelmann, C. M., Jr., and Spitzer, A.: The maturing kidney, a modern view of well-balanced infants with imbalanced nephrons. J. Pediat., 75: 509 (1969).

7. Hankes, L. V., Politzer, W. M., Touster, O., and Anderson, L.: Myoinositol catabolism in human pentosurics. Ann. N. Y. Acad. Sci., 165: 564 (1969).

8. Howard, C. F., Jr., and Anderson, L.: Metabolism of myo-inositol in animals. II. Complete catabolism of myo-inositol- ${ }^{14} \mathrm{C}$ by rat kidney slices. Arch. Biochem. Biophys., 118: 332 (1967).

9. Lewin, L. M., Szeinberg, A., and Lepkifker, E.: Gas chromatographic measurement of myo-inositol in human blood, cerebrospinal fluid and seminal fluid. Clin. Chim. Acta, 45: 361 (1973).

10. Melmed, S., Bank, H., and Lewin, L. M.: Clinical significance of increased serum myo-inositol levels. Isr. J. Med. Sci. 10: 1518 (1974).

11. Melmed, S., Lewin, L. M., and Bank, H.: Myo-inositol clearance in renal failure and in patients with normal kidney function. Amer. J. Med. Sci. 274: 55 (1977)

12. McKibbin, J. M.: The determination of inositol, ethonolamine and serine in lipids. Methods Biochem. Anal., 7: 111 (1959).

13. Ogasa, K. Kuboyama, M. Kiyosawa, I., Suzuki, T., and Itoh, M.: The content of free and bound inositol in human and cow's milk. J. Nutr. Sci. Vitaminol., 21: 129 (1975).

14. Passwell, J. H., Modan, M., Brish, M., Orda, S., and Boichis, H.: Fractional excretion of uric acid in infancy and childhood. Arch. Dis. Childhood, 49: 878 (1974).

15. Perles, R., and Colas, M. C.: Determination microbiologique du méso inositol sanguin. Clin. Chim. Acta, 5: 95 (1960).

16. We acknowledge the skillful technical assistance of Mr. Amos Gabso.

17. This work has been supported, in part, by a grant to Professor L. M. Lewin from the Office of the Chief Scientist, Israel Ministry of Health.

18. Requests for reprints should be addressed to: S. Melmed, M.D., Department of Internal Medicine, Chaim Sheba Medical Centre, Tel-Aviv University, Sackler School of Medicine, Tel-Hashomer (Israel).

19. Received for publication January 10, 1977

20. Accepted for publication May 6, 1977.
Cord blood

$17 \alpha$-hydroxyprogesterone infancy newborns

ovarian maturation total corticosteroids

\title{
Ontogenic Study of Plasma 17 $\alpha$ - Hydroxyprogesterone in the Human. I. Postnatal Period: Evidence for a Transient Ovarian Activity in Infancy
}

\author{
MAGUELONE G. FOREST ${ }^{(44)}$ AND ANNE-MARIE CATHIARD \\ Unité de Recherches Endocriniennes et Métaboliques chez l'Enfant, INSERM U-34, Hôpital Debrousse, Lyon,
} France

Summary

Plasma concentrations of $17 \alpha$-hydroxyprogesterone (OHP) were measured by a specific and sensitive radioimmunoassay in 348 blood specimens of male and female infants from birth to 2 years of age. Total corticoids levels were assayed by a competitive protein binding technique.

OHP levels were higher in the cord than in the peripheral blood of both the mother and the newborn. At term OHP cord levels were higher in female than in male infants. Mean peripheral concentrations of OHP were $419 \pm 217$ in boys and $431 \pm$ $175 \mathrm{ng} / \mathrm{dl}$ in girls in the first day of life and decreased during the first week of life to $70 \pm 37.5$ and $95 \pm 39 \mathrm{ng} / \mathrm{dl}$ in male and female infants, respectively. Thereafter, a sex-linked difference in the pattern of OHP plasma concentrations was observed during infancy and, moreover, this dimorphism varied with age, values being higher in boys at 1-2 months but higher in girls at 6-9 months of age. Total corticoids values did not vary significantly with either sex or age.

The pattern of OHP in boys closely parallels that which we described previously for testosterone and further documents the postnatal endocrine activity of the testis. The pattern of OHP in girls suggests that in human infant the ovaries exhibit a moderate and rhythmic endocrine activity which lasts at least until the end of the first year of life.

\section{Speculation}

It has been shown that in human infant the testis has a marked and transient (for about 4 months) endocrine secretion (OHP and testosterone) after the postnatal activation of the hypothalamopituitary function. In contrast, in female infants, the ovaries exhibit a moderate, rhythmic, but more prolonged endocrine secretory activity (OHP and estradiol). This could result from a pulsatile secretion with great amplitudes but a low tonic gonadotrophin activity in infancy. It is speculated that in the ovary a more sustained luteinizing hormone (LH) (or LH + follicle-stimulating hormone (FSH)) stimulation could be necessary to achieve full maturation of its steroidogenic enzymes, in particular, of the aromatase.

We have been able to demonstrate in previous studies (9-11, 13) that there is transient postnatal testicular activity in the human. This phenomenon appears to be under the control of the hypothalamic-hypophyseal axis since circulating levels of LH and FSH are markedly elevated in this period $(6,13,37)$. A similar postnatal activation of the hypothalamic-hypophyseal system was also observed in female infants $(6,13,37)$. The purpose of this work was to investigate whether the infantile ovary was capable of responding to the elevated FSH and LH 